\title{
SPORT U TRANZICIONIM DRUŠTVIMA - NESTANAK ULOGE I GUBITAK REZULTATA
}

\author{
Miloš Šolaja ${ }^{1}$ \\ ${ }^{1}$ Fakultete političkih nauka, Univerzitet u Banjoj Luci, Bosna i Hercegovina
}

\section{SAŽETAK}

Posmatrajući društvenu tranziciju kao kompleksnu mrežu društvenih promjena u svim aspektima društvenog života neizostavno je poređenje i promjena u sferi sporta u post-socijalističkim društvima $\mathrm{u}$ tranziciji u odnosu na razviijeni sistem sporta na globalnom nivou, posebno nakon kraja Hladnog rata i krupnih strukturalnih promjena početkom 90-tih godina 20. vijeka. Ako se tranzicija u postsocijalističkim društvima posmatra kao potreba napuštanja kolektivističkih vrijednosti neuspješnog globalnog projekta soijalizma u pravcu vrijednosti liberalne demokratije onda postaje vidljivo da je sportski društveni podsistem ostao netransformisan i nerazvijen, istovremeno $\mathrm{i}$ indikator neuspješno sprovedenih transformacija i prepreka za razvoj. U većini tranzicionih zemalja, koje još nisu dostigle društvene standarde neophodne za evropske integracije, ni sport nije ostvario onu ulogu koju treba da predstavlja u društvima liberalne demokratije i tržišne ekonomije uprkos činjenici da je postao dio evropskih i međunarodnih politika u oblasti sporta. Ovaj rad bi trebalo da ukaže na vrijednosni ovkir u kojem se ostvaruje društveni sportski podsistem u tranzicionim post-socijalističkim društvima, na odnos sporta i društva, vrijendosnu i ekonomsku ulogu sporta u političkom sistemu i da istovremeno istražuje zašto je u tranzicionim zemljama sport zanemaren kao oblast na koju se šire međunarodne integracije, odnosno koliko je to u konfliktu s vrijednostima iz kojih je proistekao sport i kako korespondira sa onima za koje su se opredijelila društva u tranziciji.

Ključne riječi: konzumerizam, profit, sistem, sport, transformacija, tranzicija, vrijednosti.

Prvu polovinu aktuelne 2014. godine obilježilo je svjetsko fudbalsko prvenstvo za koje su mnogi u političkoj i medijskoj sferi rekli da po značaju i obimu prevazilazi i olimpijske igre. To je novina koja pokazuje važnost ekonomske strane, komercijalizacije i profesionalizacije sporta. Olimpijade, ma koliko i same profesionalizovane i komercijalizovane, ostaju u sjenci zbog „dekubertenovske“ opaske „važno je učestvovati“. Poruka je jasna, pobjeda po svaku cijenu postaje neskriveni imperativ i krajnji cilj koji se dobro naplaćuje. Dio toga jeste i animacija publike što može da se vidi po uređivačkim pristupima globalnih informativnih kanala i mreža, isto kao i lokalnih, koji pokazuju glad za novim tipovima televizora, organizacione pripreme za gledanje utakmica i sve druge marketinško-komercijalne aktivnosti. $\mathrm{U}$ isto vrijeme sportski sistem jugoistočne Evrope iznenadio je, bolje rečeno frapirao, slučaj beogradskog fudbalskog kluba Crvena Zvezda koja je kažnjena od strane Evropske fudbalske federacije (UEFA) zbog neisplaćenih obaveza prema sopstvenim igračima. Odluci UEFA-e nije pomogla činjenica da se radi o bivšem šampionu Evrope što se kao vrijednosna kategorija intenzivno koristi u lokalnim okvirima u nastojanju da se ostvari viša društveno i ekonomski valorizovana pozicija nego što je daje recentni realni sportski rezultat. ${ }^{1}$

${ }^{1}$ Svake godine slave se nekadašnji uspjesi u međunarodnim takmičenjima. Fudblaski klub „Crvena zvezda“ (Beograd, Srbija) intenzivno bilježava pobjedu u Kupu šampiona (prethodnica Lige Evrope) 1990. kao što Rukometni klub „Borac“ Banja Luka (Republika Srpska, Bosna i Hercegovina) obilježava pobjedu u Kupu šampiona 1976. godine. $\mathrm{Ni}$ jedan ni drugi, kao ni brojni drugi klubovi nemaju od tada do danas ni jedan približan sportski uspjeh. 
Oba signala su uglavnom jasna. Prvi je da svjetsko prvenstvo predstavlja korak dalje u konzumersitičkom i ekonomsko-marketinškom pravcu dalje upotrebe sporta kao robe-usluge sa društvenim posljedicama. Drugi je da razvoj sporta u totalitetu društvenih odnosa tranzicionaih društva uzimamo kao nedovršen i netransformisan, a ujedno i vrijednosno nedorađen, društveni pod-sistem kao dio cjelokupne društvene strukture. Definišemo ga u okvirima diferenciranih političkih i ekonomskih promjena u koje su ušla tranziciona društva nakon urušavanja socijalizma kao jednog od dva do tada dominantna globalna ideološkog koncepta koji je univerzalne društvene koncepte nastojao da razrješava na osnovama prevazilaženja klasnog sukoba, a ne sukoba između država.

U skladu s takvom idološkom, filozofskom i političkom orijentacijom, sistem sporta građen je na unutrašnjim vrijednostima „vježbanja koje razvija duh i tijelo“ u nastojanjima da se razvije „socijalistički čovjek" što je radikalno mijenjalo kompetitivnu filozofiju imanenetnu sportu kao humanoj djelatnosti.

Sport je: mehanizam ispoljavanja zajedništva, [...] mehanizam apsorbovanja i trošenja viška energije [...] način bezazlenog pražnjenja agresivne i nagomilane energije [...] kultura tijela [...] prostor u kojem se čovjekova ograničenja ukidaju [...] sredstvo uspostavljanja međuljudskih odnosa (Kovačević, 2000, str. 38-40).

Orijentacija socijalizma prema sportu odnosi se i na opštu vrijednosnu predstavu sporta kao „duboko interesovanje $i$ angažovanje za sudbinu drugog čoveka u onom slučaju sportiste" (Koković, 2000, str. 163). Prihvatajući opšte ljudsko određenje sporta, socijalističko društvo počinje da razvija ovu tvorevinu modernog svijeta, ali da je oblikuje na svoj način nastojći da je upotrijebi u svrhu realizacije sopstvenih vrijednosti i društvenih ciljeva. To, naravno, podrazumijeva i potpuno nove vrijednosne osnove i elemente - umjesto liberalnog kompetitivnog modela koji polazi od osnovne postavke da su sportski rezultat i njegov nosilac proizvod kapitalističkog društva i njegovih vrijednosti vođene logikom kapitala i profita u sportu kao „društvenoj industriji““ stvara se predstava o sportu kao mogućnosti ostvarenja „novog čovjeka" - izraza ideološke težnje o društvu kojem će se doprinositi prema mogućnostima, a uživati prema potrebama. Time je socijalističko društvo, u svom inicijalnom obliku u Sovjetskom Savezu, preuzelo sport kao tvorevinu modernog kapitalističkog društva s nastojanjem da je prilagodi svom, isključivom ideološkom, opredjeljenju i unutardržavnom političkom obrascu. Moderni sport, oslonjen na takmičarski obrazac nastao je tamo gdje i moderna buržoaska država - u Engleskoj i vrlo brzo je počelo globalno širenje.

Van svake sumnje, engleski „,model“" sporta i njegovo brzo širenje bili su u funkciji pionirskog iskustva i pionirske uloge Engleske u industrijskom kapitalizmu. Štaviše kada je tamo do 1880. već dobro zagazila u „drugu fazu industrijalizacije“, Engleska je je bila na vrhuncu moći (Skembler, 2007, str. 75).

Većina sportova nastala je u anglo-američkom prostoru i do danas u osnovi čine nepromijenjeni sadržaj olimpijskih igara. Od jedanaest disciplina na prvom sportskom takmičenju između Oksforda i Kembridža 1864. godine danas je u progamu modernih olimpijskih igara čak devet.

Društveni položaj sportiste u socijalizmu od samog početka označen je pozicijom idndividue koje je pipadala drušvu - socijalističkom kolektivitetu. Kolektivitet se ostvarivao na više nivoa - od škole i sportskog kluba do grada ili univerziteta, najviši je bio država. U skladu s marksističkom definicijom klasne borbe, kao globalnog društvenog konflikta koji je pretpostavljao nestanak države, i u skladu sa svojom spoljnom politikom koja je od osnivanja smatrala da će pobijediti globalni proletarijat kao klasa i „dokinuti““ državu i konfliktne odnose među državama, Sovjetski Savez nije ni podrazumijevala uspostavljanje političkih odnosa s drugim državama. Automatski to je značilo da ne učestvuje u međudržavnim sportskim takmičenjima. Kvalitetni vrhunski sport, umjesto postizanja takmičarskog rezultata kao osnovnog motiva, stavlja se isključivo u ulogu pokretača sportsko-rekreativne masovnosti kao osnove i za potrebe kolektivne masovne ideologije. Socijalistička vlast, kao i sve vlasti, zasnovane na totalitarizmu, u tu svrhu kao vrhunsko dostignuće sportske aktivnosti organizuju takozvane „sletove“ - masovne sportske priredbe koje su apsolutna negacija kompetitivnosti $i$ rezultata $i$ ističu beznačajnost individue u kolektivistički izolovanom društvu. U političkom smislu mobilizacija masa i kolektivizacija političkih aktivnosti predstavlja osnovu političkog angažmana birokrataskog sloja koji se sve više odvaja od „osnove“ na kojoj su nastali. To izdizanje „birokratskog sloja“, određene vrste posebne socijalističke birokratske društvene kaste, odvojene od onih za koje se deklarativno izdaje, prati i diferencirani rast vrhunske sportske, partiji odane, birokratije koja se razvija u dva pravca: prvi je uloga političara kao „benevolentnih“ rukovodilaca sportskih asocijacija i klubova; drugi je društveno rangiranje i kasnije materijalno priznavanje sportskog rezultata eufemiziranog u raznim ideološki usmjerenim priznanjima tipa „narodnog sportiste“, „zaslužnog sportiste“ 
i sličnih čime se uspjeh u sportskom takmičenju definitivno dobija materijalnu kapitalizaciju iako na posebno eufemiziran način. Ona je istovremeno i neposredna - materijalna u stanovima, materijalnim dobrima i novcu, a posredna kao nagrada u društvenom položaju.

Socijalistički blok proaktivno nije stvarao niti je na bilo koji drugi način stvorio sopstvene sportske discipline kao takmičarsku podlogu u međunarodnim relacijama već je u potpunosti kopirao sportove nastale u krilu modernog kapitalizma. Kopija je odnosila na sadržaj discipline i suštinu takmičenja, oblik treninga, ali i na položaj sportiste i valorizaciju njegovog rezltata kroz definisanje sistema i vrijednosti takmičenja. „Nezapadne kulture dobijaju orijentalističko samorazumijevanje koje faktički pomaže u pobjeđivanju zapadnog racionalizma" (Giulianotti, 2008, str. 303). Socijalistički ideološki kolektivizam je trebalo da se gradi kao sui generis sportski sistem čiji je cilj bio da pokaže nadmoć nad zapadanjačkim ,iskrivljenim“ poimanjem sporta kao specifične društvene robe i masovne potrošačke robne euforije. To ne bi bilo moguće da je sport u socijalizmu ostao zatvoren u svoj ideološki oklop i da nije morao da pokaže svoju nadmoć u odnosu na suprotni svijet. Konkurencija vrijednosti socijalizma prema liberalnoj demokratiji u osnovi je prvi liberalistički pokret i put procesa koji se danas prepoznaje kao tranzicija sporta u tranzicionim postsocijalistčkim društvima. Put ka tome vodio je preko međunarodnih takmičenja.

Razmišljanja o tome počinju tek je pred nacističkom opasnošću i nakon ulaska Sovjetskog Saveza u Društvo (Ligu) naroda 1933. Staljin je tih godina redefinisao klasno-marksistički međunarodni pristup „diktaturi proletarijata“ tvrdnjom da je moguća izgradnja socijalizma u jednoj - izdvojenoj državi, različitoj od Zapada, što se u to vrijeme moglo odnositi samo na Sovjetski Savez kao jedinu državu socijalizma. Tom definicijom otvoren je Sovjetskom Savezu put međunarodnim takmičenjima, ali nije „ušao u trku“ odmah. Tek mnogo kasnije izlazi na međunarodnu scenu prvi put učestvovao na Olimpijskim igrama - 1952. u Tampareu (Finska). Time se kompetitivnost, odnosno pobjeda kao cilj cijelog procesa priprema u sportu, postavlja i kao princip u političkim odnosima među državama. Tome je doprinijela i nova geopolitička realnost - u ,istočnom“ - socijalističkom bloku pojavljuje se niz država, prethodno kapitalističkih, koje je vihor Drugog svjetskog rata pod okriljem i pritiskom sovjetske vojne moći i ideološke prisile „transformisao" u socijalističke. Koliko god da je sportski pokret u ,starom“ sovjetskom socijalizmu, kao i u državama novoproklamovane „narodne demokratije ${ }^{\text {“2 }}$ u svojoj

\footnotetext{
${ }^{2}$ Izgradnja socijalizma pod Staljinovim ideološkom palicom nije tekla lako. Svjestan činjenice da poražene zemlje Istoč-
}

ideološko-političkoj osnovi postavljen na nedržavne, nepolitičke, neprofitne osnove, ne mijenja se činjenica da je nastao kao kapitalizacija sportskog rezultata u kapitalističkom društvu i doveo ga u poziciju upotrebe u svrhu državnih politika i takmičenja među državama u međunarodnim odnosima. Takmičenje među državama značilo je permanentnu konfrontaciju dva ideološka projekta, dva geopolitčkih cilja, dva politička i ekonomska sistema, dva vojna bloka i koncepecije i doktrine. Ono što je Marks nazivao društvenom ,nadgradnjom“, odnosno što je predstavljalo sferu kulture kao oblika hegemone društvene strukture, postalo je dio takmičenja globalnih državnih blokova kao načina da se dokaže prestiž i stekne strateška prednost u okviru globalnih političkih konfrontacija. Ta vrsta konfrontacije prenosi se i na sferu nastojanja ostvarenja kulturne hegemonija čime sport kao oblast, katakeristična po jednostavnoj mjerljivosti uspjeha, postaje dio globalnog strateškog nademtanja velikih sila, ali $\mathrm{i}$ istovremeno učešća malih sila, malih i drugih država da pokažu da su prisutne i da učestvuju u svjetskim procesima. Jačim socijalističkim državama sport je služio da se ostvare na međunarodnoj sceni. ${ }^{3}$

Čin takmičenja (kompeticije) na međunarodnoj sportskoj poziciji predstavlja prvi čin liberalzacije na globalnoj sceni. Iako se pobjeda u samom sportu ne postavlja kao imperativ odnosno uspostavlja se princip učestvovanaja, a ne pobjede kao vrhovni etički princip $^{4}$, umjesto sportista kao individua pobjedu zahtijevaju države u ime svojih ideološko-političkih strateških ciljeva. Pobjeda kao politički imperativ nije mogla da bude ostvarena bez ličnih ambicija učesnika u sportskom procesu - da li se radi o ličnom uspjehu samog sportiste koji realizuje taj „visoki“ državni cilj

ne i Centralne Evrope ne mogu preko noći da postanu članice ,socijalističke zajednice“ Staljin definiše takozvanu „narodnu demokratiju“ kao prelazni oblik iz kapitalizma poraženih kalitalističkih klika od kojih je većima kolaborirala s nacističkom Njemačkom prema socijalizmu. Osnova je bila jednopartijska vlast sastavljena od predstavnika ranijih komunističkih partija, predstavnika pokreta otpora, izbjeglih sunarodnika u Sovjetski Savez kao i ideološko-političkih konvertita.

${ }^{3} \mathrm{Na}$ Olimpijskim igrama u Helsinkiju Sovjetski Savez nije osvojio ni jednu zlatnu medalju, ali je zato kao „heroj socijalizma" slavljen Čeh(oslovak) Emil Zatopek koji je osovojio dvije zlatne medalje u trčanju na ,dugim prugama“. Potrebno je analizirati kasnije uspjehe Rumunije, Poljske, Demokratske Republike Njemačke (DDR) koji su mogo ulagali u sportske uspjehe, posebno u individualne sportove proizvodeće praktično ,sportske mašine“ za pobjedu, veoma često i ne birajući sredstva.

${ }^{4}$ Prvi sekretar a porom predsjednik Međunarodnog olimpijskok komiteta Pjer de Kuberten definiše sportski etički princip izrekom: „Važno je učestvovati“. 
ili treneru i sportskom funkcioneru, irelevantno je -i jedno i drugo su idnvidualni čin preduzetništva i preduzimljivosti u jednom društvenom pod sistemu, dijelu društvene strukture koji dekondira ista takva nastojanja na suprotnoj političkoj strani - takmičenja korspndiraju jedni drugima i čine jednu od globalnih sfera u kojima se oblikuje i jedna globalna društvena struktura. Time se u državno političkom okviru kao institucionalizaciji ideološkog kolektivizma pojavljuje klica individualizma kao jedna od temeljnih vrijednosti liberlne demokratije. Stoga se može smatrati da je tranzicija u sportu počela onog trenutka kada su države zasnovane na ideologiji socijaolizma izašle na globalnu takmičarsku arenu.

Sport postaje idndividualizovan i, poput trgovine i malih usluga koje ni jedan sistem od postanka ljudske zajednice i društva u cjelini do danas nije mogao da ideologizuje i urami u državno-sistemske kolektivitičke stege, samodefiniše se kao jedna od elementarnih individualnih i društvenih funkcija i pojavljuje kao osnova individualizacije koja će se kasnije prenijeti u sve sfere društvene strukture kao osnova urušavanja socijalizma. Socijalizam i vrijednosti kolektivizma prestaju da čine način rješavanja društvenih konflikata i liberalna demokratija ostaje dominantan oblik demokratije ${ }^{5}$ organizacije društava zasnovanih na ovim vrijednostima ili koja tome teže. Pitanje koje se neminovno postavalja jeste šta je tranzicija i kako se proces promjene ukupnih vrijednosnih osnova i vrijednosne strukture društava koja su stupila u te promjene odnosi prema sportu kao nerazdvojivom segmentu društvene strukture u kojem razvijeno potrošačko društvo razvija niz potreba koje postaju potrebe pojedinca. Individualizacija glavnih aktera sportskog takmičenja, indvidualizacija publike i njihovih konzumerističkih potreba zatvaraju krug neophodne transforamcije sporta kao društvenog podsistema, čari svedene samo na spoljne forme te promjene. Spoljni „zid promjena“ ipak nije dovoljan da se sport u svojoj opštosti transformiše u pravcu istinskih tranzicionih promjena društava zahvaćenih ovim procesom i u procesu tranzicije zaostaje za dinamikom $\mathrm{i}$ intenzitetom ukupnih promjena. To u izvjesnoj mjeri utiče i na percepciju postosocijalističkih tranzicionih država kao nedovoljno ili potpuno neuspješnih. Sportska refleksija promjena u ovim državama uklapa se u neomarksističku Volerstinovu definiciju globalne međuzavisnosti po kojem se svjetski sistem sastoji od tri vrste država:

- globalni centar - bogate države, dominantne i sa snažnim vladama poput Sjedinjenih Država ili Evropske unije,

\footnotetext{
${ }^{5}$ Poznata izjava britanskog premijera iz vremena Drugog svjetskog rata koji je rekao da ,liberalna demokratija nije savršena, ali je nešto najbolje što je svijet izumio“.
}

- poluperiferija: društva koja nastoje da finansijski ojačaju, čije vlade imaju skromne mogućnosti i ograničen tehnološki razvoj sveden na razvoj konzumesrističke robe poput istočno-azijskih ,tigrova“ ili istiočno-evropskih nacija,

- periferija: države sa slabim vladama, spornim granicama i strukturalnom zavisnošću od zapadnih nacija - u velikoj mjeri afrička i latino-američka društva (Baylis \& Smith, 2001, str. 207)

Rezultati sportskih takmičenja nakon završetka hladnog rata odražavaju upravo Volerstinovu percepciju globalnih odnosa. Sliku preciznije odražvaju takmičenja u kolektivnim sportovima u trouglu „društvo - država - rezultat“. Države i klubovi koji slave nekadašnje šampionske titule nisu bili u stanju da ponove te uspjehe nakon hladnog rata i početka globalnih promjena i najčešće se već prve faze takmičenja postavljaju kao nepremostiv rezultatki prag . Države iz katagorije periferije, i pored bolnih i skupih nastojanja nisu uspjele da se odlijepe od tog praga, klubovi i sportisti iz država „druge kategorije“ - poluperiferije ponekad su i dospijevali u drugu fazu, ali ne i na sam vrh. Drugačija slika ne bi odgovorila procesima tranzicionih promjena i ne bi dala pravi odgovor o stvarnoj međunarodnoj poziciji društava i država označenih kao „novodošli“" (,new-comers") u globlanu liberalnu zajednicu. Pokazuje se da su procesi „centar-periferija“ nakon pada socijalizma, kako ih je definisao Volerstin, još izraženiji u sportu. Tranzicione promjene u bivšim socijalističkim zajednicama reflektuju transformaciju cijelih zajednica u smjeru pridruživanja međunarodnom društvu koje karakteriše model liberalne demokratije. Promjene su bile koliko kompleksne toliko duboke i geopolitički važne da „poslije hladnog rata kao i postsocijalističke tranzicione promene ne predstavljaju samo interna pitanja zemalja učesnica, nego zajednički interes međunarodne zajednice. U prvom redu stoji korelacija između međunarodnog konteksta i liberalnih vrijednosti koje se odnose na inostrani koncept promjena u svim aspektima (Šolaja, 2013). Promjene su pokrenule sve sfere društvenog života od pojedinca do cijelokupnog stanovništva post-socijalističkih država Istočne, Centralne i Jugoistočne Evrope. Njihova glavna karakteristika jeste tranziciona smjena kolektivnih socijalističkih vrijednosti u vrijednosti liberalne demokratije i dizajniranje ustava i političkih sistema u skladu s tim osnovnim pravcem razvoja. Zapadni dio međunarodne zajednice bio je veoma zainteresovan da upravlja tim promjenama, iako u tom trenutku nije bio potpuno spreman za taj proces. 
U ključnom trenutku promjena ni Brisel ni Vašington nisu imali odlučujuću ulogu - zapadni politički ,krojači“, generalno gledano, bili su okupirani događajima koje nisu mogli da predvide i zbog toga su mogli samo da ih posmatraju sa strane (Whitehead, 1994, str. 52).

I pored relativne nezainteresovanosti zapadnih centara moći, društva koja su odbacila kolektivizam i opredijelila se za zapadne vrijednosti proklamovala su trenutno pridruženje Evropskoj Uniji i bliske odnose sa Sjedinjenim Državama.

Ulazak u krug zapadnih vrijednosti nije bio bezuslovan. Evropska unija je definisala uslove 1993. godine, poznate kao „kriterijume iz Kopenhagena“, koji su podrazumijvali ključne transformacije u pravcu efikasne pluralističke demokratije, vladavine prava i zaštite manjina i prihvatanje ponašanja u skladu s princpima tržišne ekonomije. Podrazumijevalo se da će društvo u tanziciji u svim svojim aspektima pokrenuti sopstvene transformacije u pravcu ispunjvanja zadatih kriterijuma, ali je očigledno da političke elite i aktuelni lideršipi nisu to sveobuhvatno shvatili. U prvom planu su se našle političke i ekonomske tranformacije dok su brojni dijelovi društvene strukture ostajali ne samo netransformisani već apsolutno netaknuti. Procesi promjena nisu zahvatile oblasti društvene nad-strukture gdje sport po razmjerama $i$ uticaju na društvo ima vodeću ulogu. U tranzicionim društvima pretavara se u „nevođenu bombu“, polu-socijalistički (polukolektivistički) hibrid, deklarativno na individualističkim osnovama, ne uspijevajući da se prilagodi postmodernim procesima. U suštini, nisu uspijevala nastojanja da se ,etos i 'životni stilovi' novih srednjih klasa ili 'japija' obrazuju kao dominantni ideološki kulturni projekat u okviru postmodernog kapitalizma“" (Jameson, 1991, str. 406-407). Menadžment sporta postaje konfuzan i dezorijentisan, ne definiše se vlasništvo koje ostaje i dalje „opšte-društveno"66, ali na nedefinisanim društvenim ciljevima. Takva struktura animira relativno visoko asocijalan i društveno neodređen konglomerat „menadžera“, „agenata“, „sponzora“, „medijskih magnata“, „sportskih medijskih eksperata“, lobija i kolektivnih interesa sportista (sindikalizacija). Osnovni cilj postaje pobjeda u funkciji pojedinačnog, grupnog i u društveno-političlom smislu pretežno lokalnog

${ }^{6} \mathrm{O}$ tome govore postojanja „skupštine klubova“ koje se biraju na potpuno nejasnim osnovama i principima, praktično po principu da pojedini interesni konglomerati, okupljeni oko sportskih klubova zakonski registrovnih kao nevladine organizacije odnosno udruženja gađana, imenuju sami sebe, a zatim kroz proces donošenja odluka legalizuju sopstvene interese interesa pri čemu se ne biraju sredstva za dostizanje tih ciljeva. Nove društvene elite, možda preciznije može da ih opiše odrednica ,nova politička klasa“, koriste sport da ostvare neki od trenutnih interesa. Najčešće se radi o političkoj potrebi ostvarenja trenutnog političkog interesa koji se svodi na izbore ili pritisak na protivničku stranu.

Sportske strukture najčešće upotrebljavane s tim namjerama su navijači kao formalno labavo nekontrolisani, ali dovoljno sačuvani populistički element koji značajno može da doprinese politički očekivanom cilju. Koristeći isključivo i jedino „ljubav prema klubu“, kao osnovu svoje organizovane, u suštini difuzne i ponekad teško kontrolisane, političke, moći u odnosu na sportske organizacije ove grupe uzimaju sebi za pravo da ocjenjuju rezultate klubova, da utiču na postavljanje i smjene menadžmenta. Uticaj političkih i policijskih struktura na ovakvo okruženje, u suštini nastalo na kriminogenim društvenim osnovama, ne bi mogao da bude ostvaren da u sportu tranzicionih država ne postoji korupcija kao sredstva za postizanje rezultata odnosno da se sportski rezultat ne ostvaruje kombinacijom političko-ekonomskih koruptivnih djelovanja. Simbioza zastarjelih odnosa u sistemu organizovanja sporta i novih vrijednosnih orijentacija kako sportista, tako i političkih struktura usmjerenih na politički rezultat kao posljedicu dovela je do „kolonizacije“" sporta u kojem veliki i moćni kupuju njabolje što nude mali da bi ostvarili svoje ciljeve po modelu „sportskog proizvoda“ kao robe. U tom procesu neke lokalne sportske zvijezde uspijevaju da postanu dio međunarodnog sportskog establišmenta, taj svijet ostaje nedostižan i zatvoren za lokalne klubove i sportske saveze. Neke zemlje poluperiferije, uglavnom novoprimljene članice Evropske unije, nalaze se u kolonijalnom sportskom odnosu prema razvijenim državama „centra“, ali su istovremeno i cilj kolonijalizovanih sportista iz nerazvijenih država periferije. Vrijednosne promjene i organizacija sporta u tranzicionim državama nisu u stanju da brzo dostignu nivo uspostavljen u društvima razvijenog kapitalizma. Ako se u nekim istočnim država napravio korak ka sredini, u prostoru Zapadnog Balkana (geografski prostor u okvirima jugoistoka Evrope) kao posljednjoj geografskoj enklavi u procesu pristupanja EU, proces nije odmakao od početka.

Sportski klubovi, kao bazične sportske institucije nisu pretvorene u organizacije spremne da učestvuju u međunarodnim sportskim takmičenjima i udruženjima. Pravno i organizaciono nastavljaju da postoje kao ,nevladine organizacije“ ili „udruženja građana“ što je arhaičan oblik „društvenog“ ili „državnog“ ekonomskog 
vlasništva sportskih organizacija smatranih kao izraz „opšte-društvenog interesa“. Čak i kada nestanak socijalizma postaje jasan ovaj napušteni plemeniti i društveno orjentisan cilj ostaje vrijednosno formalno glavni. Mijenjajući pravno i formalno oblik organizovanja sportskih organizacija u društvenom vlasništvu nastaje vakuum u zaglavljenosti staromodnih oblika rukovođenja i upravljanja (Šolaja, 2013, str. 77).

Formalno oslabljena moć tradicionalnih sportskih društvenih funkcija uspostavila je ,fantomske vlasnike“ sportskih institucija - na koje se ne može računati u smislu obezbjeđenja egzistiranje i funkcionisanja sportskih organizacija i koji nisu osjećali pretjeranu ni obavezu, ali ni potrebu za finansiranjem, samo su nastavili da koriste finansijske i političke beneficije.

Određena vrsta vlasništva nad klubovima i timovima na zapadnom Balkanu uglavnom označava nepostojanje zvaničnog vlasništva nad klubovima, timovima i naziva se egzotičnim tipom vlasništva koje bezuslovno označava neidentifikovano vlasništvo, zbunjujući sistem rukovođenja i arhaičan sistem takmičenja (Grujić, 2013, str. 62).

Tranzicija vrijednosti i pojava ,nove klase“ ubrzali su nastojanja da se sport uključi u globalne tokove, ali se svojim sebičnim pristupima i usko individualnim i grupnim interesima nisu kvalitetno i dovoljno odredili prema postmodernističkim procesima u razvoju kulture (to znači i sporta) krajem 20. vijeka, jer principijelno uključenje u globalne tokove ne bi zadovoljili njihove funkcionlne uslove.

Globalne promjene odnose se na „postomodernističke“ ili „haotične“ odnose proizvodnje čija se refleksija u sportu ogleda kroz ekonomske podjele unutar nacionalnih zajednica dok globalnim sistemom dominisra „transnacionalna kapitačlistička klasa“ (Sklair, 1995, str. 61). Skler tu ,klasu“ naziva ,nekom vrstom međunarodne menadžerske boržoazije“. Ta klasa se sastoji od onih koji imaju globalnu moć u interesnom savezu s lokalnium partnerima. To su „kapitalizmom insiprisani političari“،, sportski profesionalci i grupe potrošača čiji je osnovni cilj da povećaju masovnu kupovnu moć kroz „kulturnu ideologiju konzumerizma“, stvaranje kupovnog raspoloženja i „konzumerističkog viđenja svijeta“ koje prevazilazi nacionane granice (Giulianotti, 2008, str. 294). Ovo postaje model po kojem se kontroliše međunarodni sport. Sportskee elitne igre i elitni pojedinačni sportovi kontrolišu međunarodne političke i poslovne elite, uključujući medijski biznis i sportove na lokalnom nivou. Sport postaje „peta industrija svijeta“", po značaju naposredno poslije naftne, vojne, farmaceutske $i$ industrije savremenih tehnologija komunikacije (Pavlović, 2007). Industrija takmičenja, marketinga i reklame, fenomeni modernog potrošačkog društva, izgradnja sportskih hala, kladionice, sportsko-informativna i oblast marketinga, postale su ne samo veliki dio modernog života pojedinca, već i jedan od najvažnijih sadržaja ekonomije, samim tim i krucijalno političko pitanje. ,Industrija sporta“" postaje uticajna u savremenim globalnim politikama.

Nove političke elite kao proizvod urušavanja socijalizma, mnoge nastale i u samom njegovom krilu, proklamovale su kapitalističli model sporta kao konzumeristički orijentisanog proizvoda, ali da pri tome nisu razumjele i pokrenule promjene na nacionalnom nivou. Dok su u globalnoj međunarodnoj sferi nastojali da postanu dio postmodernističkog globalnog establišmenta, na unutrašnjem, nacionalnom ili unutardržavnom, ostale su tradicionalne sportske autokrate koji su sport uvažavale kao sredstvo za ostvarivanje trenutnih političkih ili eventalno materijalnih interesa. Dok se liberalizacija u sportu na međunarodnom planu uvažava kao princip i sistem vrijednosti kojima se teži na lokalnom nivou ostaje netransformisana sfera društvenosti u političkom, ekonomskom i, generalno gledano, strukturalnom, pogledu. Iz te vrijednosne dihotomije nastaje potreba da se transformacije sporta koje u smjeru aktivne participacije u međunarodnom sistemu sporta čak i sprečavaju. ${ }^{7}$ U većini zemalja u tranziciji, ali i velikim dijelovima nerazvijenog svijeta, napuštanje starog koncepta narušava globalno robno-ekonomsko pozicioniranje sporta. „Neoliberalne politike opustošile su infrastrukturu zemalja u razvoju“ (Giulianotti, 2008, str. 293).

U vrijeme kada u sistemu vrijednostu u kojem sportski uspjeh nije morao obavezno da bude bitno valorizovan iz konzumerističko-političkog ugla krije se i dio tajne da su neka društva svojevremeno mogla

${ }^{7}$ Pokušaj da se Rukometni klub „Borac“ Banja Luka (Republika Srpska, Bosna i Hercegovina), koji gotovo u svakoj prilici ističe svoje dvije međunarodne šampionske titule, „brendira“ kroz prodaju dresova-kopija, šalova, kapa ili pretplatu na sjedišta, organizaciju rukometnih škola i izgradnju sopstvene sportske dvorane, nije uspio. Konzervativne snage bile su usmjerene na finansiranje iz ranijih „sigurnih“ izvora - generalni spozor kojega nije mnogo zanimao rezultat i javnih budžeta. To je bio način da se klub održi pod kontrolom političko-ekonomskih interesnih grupa koje nije mnogo zanimao liberalni pristup sportu, a da se dio sportskog menadžemanta na koruptivan način obogati. 
da participraju u raspodjeli sportskih rezultata i uspjeh što i pokazuju navedeni primjeri evropskih i svjetskih titula. Dizajn i funkcionalnost sportske opreme (dresovi, lopte, rekviziti sportova sa spravama, sportske dvorane, nepromjenjive podloge itd.) sporo su se mijenjali. Tržišna uloga sporta u paradigmatskim okvirima kulturološkog konzumerizma nije bila primarna, iako je vremenom jačala. Postomodernizan donosi raslojavanje, nestaje klasična „radnička klasa“, a na globalnu scenu stupa srednji ekonomski sloj, sve brojnija ,nova klasa“ u raznolikim oblicima upravljanja, inženjeringa, posredovanja, prodaje usluga, prodaje potoršačke egzistencijalne nepotrebne robe. Ovaj sloj prihvata, ali i podstiče, potrošačku kulturu u uživanje u blještavilu konzumerizma. „U eri liberalnog kapitalizma najnovije doba razvoja na Zapadu, koje je počelo ranih sedamdesetih godina prošlog veka i obično ga nazivamo dobrom ranog ili dezorganizovanog kapitalizma bilo je svedok promena u sportu koje su se odvijale istim tempom kao i promene $u$ društvu“ (Skembler, 2007, str. 284). Neke od kulturološki identifikovanih konzumerističkih vrijednosti postaju relikvije i u tome prednjači sport. Sportski klubovi počinju često da mijenjaju dizajn opreme $i$ pratećeg marektinga, a najveću vrijednost u proizvodu dobija „brendiranje“" imena kluba ili pojedinca drugim riječima kreiranje novih identiteta zasnovanih na ,vjeri“ u konzumerističke sportske zvijezde čije marketinške poruke počinju da se upotrobljavaju i u opštenacionalnim dimenzijama.

Upravo kroz ovakvu sportsku publiku raste kapacitet primaoca (medijskih) poruka. Ona, ne samo da ih prima, već se identifikuje s njima i postaje nezaobilazni dio sportskih događaja [...] postaji dio međuljudske komunikacije, razmišljanja i što je još važnije, rezultatskih, ali i poslovnih komunikacija (Šolaja, 2001, str. 210).

Tranzicionim društvima svojestveno je da te poruke nisu lokalne, nacionalne, već međunarodne $i$ globalne. Sportovi postaju televizijski i medijski događaji ${ }^{8}$ i mijenjaju se u smjeru modernog društvenog podsistema kao značajnog globalnog okvira cjelokupnih društvenih promjena putem globalnih procesa u smislu biznisa. Uključjući komercijalizaciju informacija i industriju komunikacija industrija sportske opreme i sportski procesi postaju dio poslovne filozofije i ekonomije liberalnog društva kao roba koja se valorizuje na tržištu.

${ }^{8}$ Za Olimpijske igre u Atlanti 1996. godine kažu da su prve marketniške Olimpijske igre, jer su osnovu finasiranja činili TV prava prenošenja, industrija reklama i marketinga.
„Sportovi postaju televizijski događaji, a ne stvarni doživljaji“ (Baudrillard, 1993, str. 79-80). Međunarodni sport je podređen televiziji i industriji reklama. Ne samo vrijeme takmičenja, već i način prezentacije samih događaja podređuje se „njenom veličanstvu" televiziji i onome što ona nosi - industriji reklama. Rezultat i prateća atmosfera na terenu postaju prolazan, posredan cilj a dominantna je komercijalna industrija i sticanje profira. Publika i gledaoci postaju direktan predmet televizijske pažnje i nerazdvojni dio događaja. Realni sport nestaje, zamjenjuje ga način na koji ga predstavlja televizija što utiče na način učešća sportista i ogromnog televizijskog audio-vizijorijuma kao aktera sportskog događaja. Kulturne razlike sve više se smanjuju, a sportovi postaju globalni. Sportske federacije sve manje se prema sportu odnose kao konfederalne nacionalne asocijacije, a sve više se pretvaraju u biznis asocijacije koje nastoje da „na tržištu povećaju vrijednost svje robe, medijima upravljaju desnopolitičke političke elite uz minimalnu transparentnonst" (Hoberman, 1995, str. 36). Sportske asocijacije postepeno se pretvaraju u multinacionalne korporacije koje se posljednjih godina sve prepoznaljivije po globalnim razmjerama korupcije. Za razliku od „tradicionalne“ sportske korupcije - potkupljivanja sudija i namještanja rezultata da bi se vještački došlo do pobjede, korupcija se prenosi i na međudržavne odnose tako da predmet korupcije postaje čak i postupak odlučivanja o mjestu održavanja olimpijskih igara ili svjetskih prvenstava. Sve postaje globalni medijski i kulturološki događaj, pa i globalna korupcija.

Sport se danas sve više prepušta medijima. Mediji su najbolji primer kako se sport politizuje, širi i guta one domene ljudske svakodnevice koja je naizgled slobodna i neutralna (Koković, 2004, str. 45).

Učešće tranzicionih zemalja u globalnom medijskom sport-show ostaje neznantno i neprimjetno. Države koje s mnogo problema nastoje da dostignu nivo političkih i ekonomskih standarda i još ulažu mnogo napora u tom smjeru, nisu imale ni ekonomske mogućnosti, a ni snage da razvijaju dosljedne koncepte i strategije razvoja sporta. Čak ni glavne oblasti nisu promijenjene brzo, tako da je sport ostao na marginama procesa. U početnoj fazi promjene su se desile u sferama politike i ekonomije i nastojanjima da se uvede vladavina prava što je postavljeno kao prioritetan zadatak ,,međunarodne zajednice“ odnosno ,zapadnih moderatora“ tranzicionog procesa. Očito je da je proces, previše pod uticajem neophodnosti promjena, zahtijevao snažnije i dosljednije učešće zapadnih država. 
Element procesa demokratizacije sigurno je imao i važnu međunarodnu komponentu. Iako se sa dna pojačava pritisak ili naglašava važnost strategija političkih elita, domaće i međunarodne komponente tog procesa bile su toliko prepletene da bi ih bilo nemoguće i vještački razdvajati (Whitehead, 1994, str. 57).

Prelazak iz autoritarnog vladanja ide prema ,konsolidaciji liberalne demokratije“, djelujući na više frontova, istovremeno vodi do konsolidacije demokratije i tržišne ekonomije. Postautoritarni režimi ostaju manje-više neodređeni usljed uvođenja i razvoja novih vrijednosti. Sport se ne postavlja u prvi red vodećih politika zbog čega bi nepromijenjen mogao da predstavlja paradigmu i jedan od oslonaca za obnavljanje izvjesnih oblika i osnova autroritarnog vladanja unutar tranzicionih promena. Ovo je posebno povezano sa tranzicionim promjenama u jugoistočnoj Evropi gdje je i definisan „neuspjeh međunarodnih politika prema bivšoj Jugoslaviji što na cijeli tranzicioni proces baca priličnu veliku sjenku“ (Ibid, str. 52).

Demokratizacija Albanije i bivše Jugoslavije bila je namanje liberalna u istočnoj Evropi, jer je postala oruđe ekstremno netolerantnih nacionalista. Liberalna demokratija izgradila se u mnogo većem stepenu i mnogo brže u zemljama Istočne i Centralne Evrope (Poljska, Češka, Slovačka i Mađarska) ali sa promenjivom stabilnošću. Negdje između ova dva primjera nalazi se demokratizacija koja se dogodila u Rumuniji i Bugarskoj (Herring, str. 88).

U ovoj fazi tranzicije javlja se specifična simbioza liberalnih vrijednosti i održivosti liberalne demokratije, tržišne ekonomije i vladavine zakona i zaostalih socijalističkih vrijednosti u obliku grupno-interesnog organizovanja formalizovanih u političke partije kao organizacionu formu, koruptivnu i nekonkurentnu ekonomiju i potpuno neodgovorne pravne sisteme koji nisu u stanju da obezbijede vladavinu prava ni u jednoj oblasti života, samim tim ni u sportu koji, naprotiv, postaje prostor potunog nedostataka pravnih, ali i društvenih normi.

$\mathrm{U}$ tranzicionim društvima ne radi se samo o nedostataku zakonske regulative i pravnog ponašanja, još više je problematičan vrijednosni vakum u vremenu između napuštanja socijalizma i prihvatanja liberalnih vrijednosti pogubno uticao na razvoj sporta kao društveno odgovorne djelatnosti. Promjene u međunarodnom sportu nisu bile dovoljan motiv i cilj političkim elitama da bi usmjerile razvoj u tom pravcu. U suštini one to nisu ni željele, kao što većina njih ne želi ni članstvo svojih država u Evropskoj Uniji i drugim integracionim asocijacijama. Zatvorenost sporta pogoduje blokiranju formalno proklamovanih ciljeva. Njihov politički odnos prema sportu zadržava se na nivou „lokalnog“" spektakla - korišćenje sportskog uspjeha ili afere u sportu u dnevne političke potrebe izražene u izbornoj kampanji, u političkim prepirkama i sporovima. Nejasan vlasnički odnos u kojem klub ostaje „društveno dobro“, ali funkcioniše za račun privatnih ekonomskih i političkih interesa, najviši sportski domet organizacija postaje paradržavno organizovanje klubova i, eventualno, podrška nacionalnim reprezentacijama čiji je limitirani međunarodni uspjeh više okrenut unutrašnjim političkim potrebama nego stvarnom pozicioniranju na međunarodnoj sportskoj sceni. Kopiranje ,sovjetskog državnog modela" u tranzicionim uslovima je kratkog daha i ne nastaje kao rezultat sistematskog stvaranja „državnih timova“, već je više kompilacija nastala kupovinom individualnih sportskih uspjeha ranije proizvedenih „lokalnih zvijezda“" s vrlo limitaranima rezulatiskim ciljevima - do nivoa identifikacije publike s lokalnim političlim ečlitama.

Ovakvo para-državno uređenje sportskih institucija vidno ograničava i kvari fundamentalne elemente sporta kao društvenog pod-sistema, u prvom redu njihovo vlasništvo, nakon toga i druge sfere kao što su trening, pripreme, finansiranje, menadžment, obrazovanje i medijsku zastupljenost (Šolaja, 2013, str. 77).

Sportska takmičenja u tranzicionim državama ${ }^{9}$ posebno onima nastalim iz ranijih multinacionalnih federacija predstavljaju neuspjele kopije ranijih takmičarskih sistema, ali na mnogo nižim osnovama mobilizacije sportista, organizacije, etičkog odnosa, na kraju krajeva i ekonomske pozicije. Stoga i u medijskom smislu ostaju nezanimljiva, a publika se fokusira prema međunarodnim medijima koji stvaraju privid aktivne participacije u velikim i masovnim sprotskim događajima.

Sport i projekcija budućnosti ostavlja se onima koji se bave sportom od kojih većina nije otišla u pravcu nekog strateškog razmišljanja već ostaje na terenu individualne koristi, najčešće ostvarene na

${ }^{9}$ Zemlje Istočne i Centralne Evrope prošle su ogromne geopolitičke promjene nakon Hladnog rata. Sovjetski Savez podijeljen je na 15 novih država, raspad Jugoslavije donio je šest novih država. U oba slučaja raspada višenacionanih federacija pojavile su se i nove ,sub-države“ koje teže ka tome da dobiju status države. Uz mirno rastakanje Čehoslovačke, ukupan broj država koje sebe politički svrstavaju u prostor Evrope porasta sa 35 na 47 koliki je danas broj država članica Savjeta Evrope. 
koruptivan način. Fokusirajući se na tranzicione društvene promjene na jugoistoku Evrope, političke elite šest država Zapadnog Balkana, ali i Rumunije i Bugarske, zanemarile su oblast sporta koja najvećim ekonomskim potencijalima participira u kulturološkoj sferi i nisu uspjele da ga pozicioniraju kao važan dio ukupnih nastojanja da se dostignu ciljevi u pravcu evropskih integracija. Neuspjeh uključivanja u robno-kulturološlu konzumerističku sferu, sprečava aktivan odnos pema promjenama i nastavlja inerciju ranijeg sistema u kojem su pravna osnova vlasništva, svojine i finansijskog poslovanja ostali zarobljeni u ,nevladinom sektoru" $i$ funkcionišu po pravnim regulama za civilno društvo iako su ciljevi apsolutno profitni. Mendžament ostaje formalno opšte-društveni, ali je suštinski uspostavljen na bazi privatnih aranžmana. Uspješni dio uključenja u međunarodni sport isključivo je individualan ${ }^{10}$ i predstavljaju ga uglavnom sportisti koji svoje sportsko znanje i vještinu nastoje prodaju kao profitaabilnu robu. Većina komercijalno unosnih sportova u tranzicionim zemljama apsolutno je neprofitabilna zbog čega nema velikih ulaganja od strane biznisa niti ulaganja u njihovu medijsku predstavljenost. Tajkuni su mnogo manje prisutni u sportu nego lokalni političari koji su jako zainteresovani za poene i ugled koje im sport donosi. Predstavnici biznisa ulažu uglavnom kada neki političari iskažu potrebu s namjerom da ostvare neke druge koristi. Princip je poznat kao „,reket“ kao specifičan oblik korupcije, jer je njome i uslovljnen.

Posljedica nedostatka jasne perecpecije o ulozi sporta u postmodedrnim međunarodnim odnosima i odsustvo vizije i strategije razvoja u novom vrijednosnom okruženju jeste nedovoljno organizaciono i finansijsko transformisanje na način da korespondira s međunarodnim sistemom sporta u učestvuje u podjeli međunarodnog sportskog i ekonomskog rezultata, nedefinisana transformacija vlasništva koja određenom krugu pojedinaca omogućava neodgovorno upravljanje u cilju ostvarivanja individualne koristi u principu najčešće kroz korupciju i druge ekiminogene oblike upravljanja, medijsko održavanje sprota u lokalnim granicama odnosno izvan participacije u sistemu međunarodnih medija i društvenih promjena uopšte. Javne politike u sportu ne integrišu se u ukupne integracione javne politike zbog čega su apsolutno zaostale. Političke elite tranzicionih društava ne pakzuju veliko zanimanje za sport. U velikoj

\footnotetext{
${ }^{10}$ Time može da se objasni „fenomen Đoković“ - menadžemnt njegovog uspjeha nije „državni“, što i nije poželjno, ali ni proizvod regulisanja društvenog ambijenta pogodnog za razvoj sporta. To je rezultat isključivo individualnih napora takmičara $i$,family business“ da bi se postogao rezultat.
}

mjeri deklarativno za promjene, ogromna većina učestvuje u tranforamciji sporta kao pod-sistema na osnovama ekonomske ili političke korupcije što ih onemogućava da uspostave konsekventan sistem vrijednosti primjeren smjeru, dinamici i intenzitetu promjena. Jedan od pravaca pogodnih za vrijednosno određenje jeste učešće sporta u mira u izgradanji mira (General Assembliy Resolution of United Nations, 1994) kao opšteljudske vrijednosti iako se u ovom trenutku čini da bi se ključni subjekti odlučivanja u sportu radije pridružili klasno-robnom konceptu sprota kao preovlađujućem u globalnim razmjerama s obzirom na nedovršenost i nepostojanje strategija razvija sporta. Vladajućim elitama to je bliže i lakše nego da se razvijaju pristupe i aktivnosti koje bi sport vratile izvorno humanističkim i opšteljudskim vrijednostima humanosti, plemenitosti, izgradnje mira i saradnje među državama u nastojanju da se liberalističko međunarodno okruženje učini fleksibilnijim za ostvarivanje potreba ljudi.

\section{LITERATURA}

Baudrillard, J. (1993). The transparency of evil. London, Great Britain: Verso.

Baylis, J., \& Smith, S. (2001). The globalization of world politics. New York, NY: Oxford University Press.

Grujić, M. (2013). Organization, financing and ownership of sports clubs in the stock market. In S. Simovic and V. Stankovic (Eds.), 4th International Scientific Conference "Anthropological aspects of sports, physical education and recreation" (pp. 5264). Banja Luka, Bosnia and Hezgeovina: Faculty of Physical Education and Sport. doi: 10.5550/SP.4.2012.06

Giulianotti, R. (2008). Sport-kritickea sociologija [Sport - critical sociology]. Belgrade, Serbia: CLIO.

Herring, E. (1994). International security and democratisation in Eastern Europe. New York, NY: St. Martin s Press.

Hoberman, J. (1995). Toward a theory of olimpic internationalism. Journal of Sport History, 22(1), $1-37$.

Jameson, F. (1991). Postmodernism or the cultural logic of late capitalism. London, Great Britain: Verso Koković, D. (2000). Sociologija sporta [Sociology of sport]. Belgrade, Serbia: Sportska akademija.

Koković, D. (2004). Sport i mediji [Sports and media]. Novi Sad, Serbia: Fakultet za uslužni biznis

Kovačević, B. (2000). Sociologija sporta [Sociology of sport]. Banja Luka, Bosnia and Herzegovina: 
Centar za stručno obrazovanje i usavršavanje trenera - Centar za sport.

Pavlović, R. (2007, September 3). Peta svetska privredna grana [The fifth global industry]. Politika online. Retrived from: http://www.politika.rs/ rubrike/Sport/30098.sr.html

Skembler, G. (2007). Sport i drustvo [Sport and society]. Belgrade, Serbia: CLIO.

Sklair, L. (1995). Sociology of the global system. Baltimore, MD: John Hopkins Universitz Press

Šolaja, M. (2001). Globalizacija, saveremeni mediji i savremeni sport. Defendologija, 4(10), 205-214.

Šolaja, M. (2013). Sport in a neo-liberal post-socialistinternational context. In S. Simovic and V.
Stankovic (Eds.), 4th International Scientific Conference "Anthropological aspects of sports, physical education and recreation" (pp. 72-82). Banja Luka, Bosnia and Hezgeovina: Faculty of Physical Education and Sport. doi: 10.5550/SP.4.2012.08 General Assembliy Resolution of United Nations. (1994). Sport for development i peace. No. 19431. Retrived from http://www.un.org/wcm/content/site/sport/home/resourcecenter/resolutions/ pid/19431.

Whitehead, L. (1994). East-Central Europe in comparative perspective. New York, NY: St. Martin's Press.

Primljeno: 10. jun 2014 Izmjene primljene: 30 . jun 2014

Odobreno: 30. jun 2014

Korespondencija: dr Miliš Šolaja

Fakultet političkih nauka

Bulevar V. Petra Bojovića 1A 78000 Banja Luka

Bosna i Hercegovina Telefon: 0038765515112

E-mail:msolaja@teol.net 